九州大学学術情報リポジトリ

Kyushu University Institutional Repository

\title{
Application of T-RFLP Analysis for Bacterial Community Structure of Colonies Grown on Agar Plates
}

Matsuka, Akira

Laboratory of Soil Microbiology, Division of Soil Science and Plant Production, Department of Plant Resoruces, Graduate School of Bioresource and Bioenvironmental Sciences, Kyushu University

Sakai, Masao

Laboratory of Soil Microbiology, Division of Soil Science and Plant Production, Department of Plant Resources, Faculty of Agriculture, Kyushu University

Kanawaza, Shinjiro

Laboratory of Soil Microbiology, Division of Soil Science and Plant Production, Department of Plant Resources, Faculty of Agriculture, Kyushu University

https://doi.org/10.5109/4532

出版情報: 九州大学大学院農学研究院紀要. 48 (1/2)，pp.107-112，2003-10-01. Faculty of Agriculture, Kyushu University

バージョン :

権利関係 : 


\title{
Application of T-RFLP Analysis for Bacterial Community Structure of Colonies Grown on Agar Plates
}

\author{
Akira MATSUKA*, Masao SAKAI ${ }^{\dagger}$, and Shinjiro KANAZAWA \\ Laboratory of Soil Microbiology, Division of Soil Science and Plant Production, Department of \\ Plant Resources, Faculty of Agriculture, \\ Kyushu University, Fukuoka 812-8581, Japan \\ (Received June 10, 2003 and accepted July 15, 2003)
}

\begin{abstract}
As a prompt and efficient method for analysis of community structure of bacterial colonies grown on agar plates, we investigated the application of terminal restriction fragment length polymorphism (T-RFLP) analysis. To deduce the community structure of colonies grown.on agar plates, analysis of a number of colonies is necessary. In this analytical method, many colonies were collected using a Pasteur pipette to easily collect a constant amount of cells, and the colonies were collectively subjected to T-RFLP analysis to estimate the community structure of colonies. To analyze dominant bacterial species in test soils, 100 colonies were sufficient. Using this analytical method, we investigated the influence of plating method for colony count (pour-plate method vs. spread-plate method) on the constitution of bacterial species grown on the medium. Difference in plating method did not markedly change the bacterial species grown, but it did affect the constitution ratio of some bacterial species.
\end{abstract}

\section{INTRODUCTION}

A variety of bacterial species with various functions inhabits soils. These bacterial groups are involved in the plant production and clean-up functions of soils. To analyze the dynamics and functions of individual bacterial groups with specific functions, various selective media have been designed and used for studies of soil microorganisms. For example, selective media have been used to investigate the numbers of nitrogen-fixing bacteria and cellulose-assimilating bacteria and isolate bacteria having these functions. However, to evaluate the usefulness of these selective media and determine the application ranges, colonies grown on the medium had to be investigated one by one, which was an obstacle to development of selective media. If community structure (bacterial species and their constitution ratios) of bacterial species grown on a selective medium can be rapidly analyzed, it may be useful for design and improvement of a new selective medium.

In recent years, various methods as shown below have been developed as methods for analysis of bacterial community structure: 1) Methods using nucleic acids (gene): DNA reassociation analysis, DNA $(\mathrm{G}+\mathrm{C} \%)$ density fraction analysis, cross DNA hybridization analysis, PCR-amplified DNA clone library method, and various genetic fingerprint analyses (DGGE, TGGE, ARDRA, T-RFLP, SSCP, RISA, and RAPD) (Ranjard et al.,

\footnotetext{
* Laboratory of Soil Microbiology, Division of Soil Science and Plant Production, Department of Plant Resources, Graduate School of Bioresource and Bioenvironmental Sciences, Kyushu University

+ Corresponding author (E-mail: msakai@agr.kyushu-u.ac.jp)
} 
2000), 2) methods using cellular components (biomarkers): phospholipid fatty acid (PLFA) analysis (Arao et al., 1998), quinone profile analysis (Fujie et al., 1998), and 3) methods using carbon source-assimilating property: diversity analysis based on the carbon source utilization patterns of isolates (Yokoyama, 1996), and community-level physiological profile (CLPP) analysis (Konopka et al., 1998). These methods allowed rapid progress of studies of bacterial community structure. Particularly, terminal restriction fragment length polymorphism (T-RFLP) analysis is superior in simplicity, sensitivity, and reproducibility (Liu et al., 1997; Marsh, 1999; Moeseneder et al., 1999).

In this paper, we investigated the application of T-RFLP analysis as a prompt and efficient method for analysis of community structure of colonies grown on agar plates. Furthermore, using this method, changes in community structure of colonies due to differences in the plating method for colony count (pour-plate method vs. spread-plate method) were investigated.

\section{MATERIALS AND METHODS}

\section{Soil sample and plate dilution culture method}

A soil sample collected from a strawberry-cropping field located in Yunoura, Kumamoto Prefecture was passed through a $2 \mathrm{~mm}$-sieve and used as the test soil. According to the dilution plate method described in Experimental Methods of Soil Microorganism (1992), suspensions of soil dilutions were prepared and plated by the pour method or spread method on four plates at each dilution step. Plates were incubated at $28^{\circ} \mathrm{C}$ for 10 days. As medium for aerobic heterotrophic bacteria, 0.1 TSA medium (peptone, $1.7 \mathrm{gL}^{-1}$; soytone, $0.3 \mathrm{gL}^{-1}$; glucose, $0.25 \mathrm{gL}^{-1} ; \mathrm{K}_{2} \mathrm{HPO}_{4}, 0.25 \mathrm{gL}^{-1} ; \mathrm{NaCl}, 0.5 \mathrm{gL}^{-1}$; agar, $15 \mathrm{gL}^{-1}$; $\mathrm{pH} 7.2$ ) was used. As medium for crystal violet (CV)-resistant bacteria, $5 \mathrm{mgL}^{-1}$ of $\mathrm{CV}$ was added to $0.1 \mathrm{TSA}$ medium, $0.1 \mathrm{TSA}+\mathrm{CV}$ medium, was used.

\section{Colony collection and DNA extraction}

From four plates at a dilution step at which about 100 colonies were grown per plate, 100 colonies were randomly collected. To obtain a constant amount of cells from colonies with a diameter greater than $1 \mathrm{~mm}$, colonies were sucked with medium one by one using a Pasteur pipette ( $1 \mathrm{~mm}$ inner diameter at the tip). These 100 colonies were placed in a $2-\mathrm{ml}$ microtube with a screw cap. To the microtube, glass beads $(2.5 \mathrm{~mm} \phi, 0.06 \mathrm{~g} ; 1 \mathrm{~mm}$ $\phi, 0.3 \mathrm{~g} ; 0.5 \mathrm{~mm} \phi, 0.4 \mathrm{~g} ; 0.1 \mathrm{~mm} \phi, 0.4 \mathrm{~g}$; BIOSPEC Co.), $400 \mu \mathrm{L}$ of SDS lysis mixture $(100 \mathrm{mM} \mathrm{NaCl}, 500 \mathrm{mM}$ Tris-HCl $(\mathrm{pH} 8.0), 10 \%$ SDS), $300 \mu \mathrm{L}$ of $120 \mathrm{mM}$ sodium phosphate buffer ( $\mathrm{pH} 8.0$ ), and $400 \mu \mathrm{L}$ of phenol: chloroform: isoamylalcohol (25:24:1, pH 8.0) were added. Using a MINI BEADBEATER (BIOSPEC Co.), cells were destroyed at $5,000 \mathrm{rpm}$ for 20 seconds. After centrifuge at $12,000 \mathrm{rpm}$ for 30 seconds at room temperature, the supernatant (aqueous phase) was transferred to a new 1.5-mL microtube. To this tube, $1 / 10$ volume of $3 \mathrm{M} \mathrm{CH}_{3} \mathrm{COONa}(\mathrm{pH} 4.8)$ and 2.5 volumes of $100 \%$ ethanol were added and mixed, and kept standing at room temperature for 10 minutes. The mixture was then centrifuged at $12,000 \mathrm{rpm}$ for three minutes at room temperature to separate DNA. The supernatant was removed, and $1 \mathrm{~mL}$ of $70 \%$ ethanol was added to the pellet, mixed slightly, and centrifuged at $12,000 \mathrm{rpm}$ for three minutes at room temperature. The supernatant was removed, and the pellet was air-dried for five 
minutes. Each DNA pellet was dissolved in $50 \mu \mathrm{L}$ of ultrapure water.

\section{PCR and restriction digests for T-RFLP}

Purified DNA (10ng) was amplified by PCR using the forward primer $63 \mathrm{f}-\mathrm{Cy} 5$ (5'-[Cy5]CAGGCCTAACACATGCAAGTC-3' [Marchesi et al., 1998]) labeled with a fluorescent dye (Cy5) and the unlabeled reverse primer $907 \mathrm{r}$ (5'-CCGTCAATTCMTTTRAGTTT-3' [Lane, 1991]). Both primers are considered to be specific for eubacteria. The reactions were performed in $50 \mu \mathrm{L}$ (final volume) mixtures containing $1 \times$ PCR buffer, $1.5 \mathrm{mM} \mathrm{MgCl}_{2}$, each deoxynucleoside triphosphate at a concentration of $0.2 \mathrm{mM}$, each primer at a concentration of $1.2 \mu \mathrm{M}$, and $1.25 \mathrm{U}$ of Taq DNA polymerase (Takara Shuzo). Samples were amplified in a thermocycler (ASTEC PC-707) by using the following protocol: an initial denaturation step at $94^{\circ} \mathrm{C}$ for $3 \mathrm{~min}$, followed by 25 cycles of denaturation at $94^{\circ} \mathrm{C}$ for $30 \mathrm{~s}$, annealing at $50^{\circ} \mathrm{C}$ for $30 \mathrm{~s}$, and extension at $72^{\circ} \mathrm{C}$ for $1 \mathrm{~min}$. Cycling was completed by a final extension at $72^{\circ} \mathrm{C}$ for 10 min. Amplification of DNA was confirmed by electrophoresis of aliquots of PCR mixtures $(2 \mu \mathrm{L})$ in $1.5 \%$ agarose in $1 \times \mathrm{TAE}$ buffer.

The PCR products labeled with a fluorescent dye were purified by using the Qiaquick PCR Purification Kit (Qiagen) according to the instructions of the manufacturer. Aliquots of the purified 16S rDNA were digested by restriction enzymes. Digestion reaction mixtures $(20 \mu \mathrm{L}$ ) contained $0.1 \mu \mathrm{g}$ of the $16 \mathrm{~S}$ rDNA and $10 \mathrm{U}$ of either HhaI (TOYOBO, Japan) in the manufacturer's recommended reaction buffers, and were incubated for $6 \mathrm{~h}$ at $37^{\circ} \mathrm{C}$.

\section{T-RFLP analysis}

The lengths of the labeled TRFs from the amplified rDNA products were determined by electrophoresis with an automated DNA sequencer (ALFexpress; Amersham Pharmacia Biotech), as follows. Electrophoresis samples containing $5 \mu \mathrm{L}$ of digestion reaction, $3 \mu \mathrm{L}$ of Loading Dye (Amersham Pharmacia Biotech), and 2 fmol Sizer50 size standard (Amersham Pharmacia Biotech) were denatured at $95^{\circ} \mathrm{C}$ for $5 \mathrm{~min}$ and then immediately stored on ice until loading onto the gel. Approximately $9 \mu \mathrm{L}$ of each sample was applied to a $5 \%$ polyacrylamide gel and run on the Sequencer for $10 \mathrm{~h}$ under the following conditions: $1,500 \mathrm{~V}, 55 \mathrm{~mA}$, and $25 \mathrm{~W}$. The laser scanning system of this DNA sequencer detected only the labeled 5'-terminal fragments. The TRF size was determined in comparison to the pattern of the external lane standard (Sizer50-500 size standard; Amersham Pharmacia Biotech).

\section{RESULTS AND DISCUSSION}

\section{Analysis of colony community structure by T-RFLP}

To investigate reliability of the method for analysis of colony community structure using T-RFLP, quadruplicate analyses were compared. The test soil was divided into four samples (A, B, C, and D) and each sample was subjected to T-RFLP analysis of colony community plated by the pour method and grown on 0.1 TSA medium. As shown in Fig. 1, $7 \mathrm{~T}-\mathrm{RF}$ peaks were detected in each sample, suggesting the presence of 7 dominant species. There were no marked differences in the T-RF peak positions (T-RF sizes) or 
relative fluorescence intensities (amounts of $\mathrm{T}-\mathrm{RF}$ ) among the samples, and the $\mathrm{T}-\mathrm{RF}$ patterns were similar. Based on this highly reproducible T-RFLP analysis, the points below are discussed.

Since soils are generally not homogenous, soil bacteria are unlikely to homogenously distribute. Accordingly, to deduce the bacterial community structure in soils, the influence of uniformity of soils is great, and different results among the repeated analyses were predicted. However, high reproducibility was obtained in this study, indicating that sufficiently homogenous dispersion of bacteria was obtained by the preparation of the test soil sample.

Next, the number of colonies selected also affects the estimation of the bacterial community structure. Torsvik et al. (1990a,b) investigated diversity of colonies of soil samples cultured on agar plates by DNA reassociation analysis and estimated that investigation of at least 90 colonies included dominant bacterial species. Accordingly, considering the work efficiency, we predicted that investigation of 100 colonies grown on an agar plate is sufficient for analysis of community structure of culturable bacteria. If 100 colonies were insufficient, i.e., if more than 100 bacterial species were present, the results of repeated analyses would not have been consistent and various patterns would have been seen. The results of the quadruplicate T-RFLP analyses shown in Fig. 1 exhibited similar patterns, confirming that in this method of analyzing bacterial community in the culture of the test soils by this method, selection of 100 colonies including dominant bacterial species was sufficient. Furthermore, use of a Pasteur pipette to collect a constant amount of cells may have lead to the good reproducibility of this analytical method.

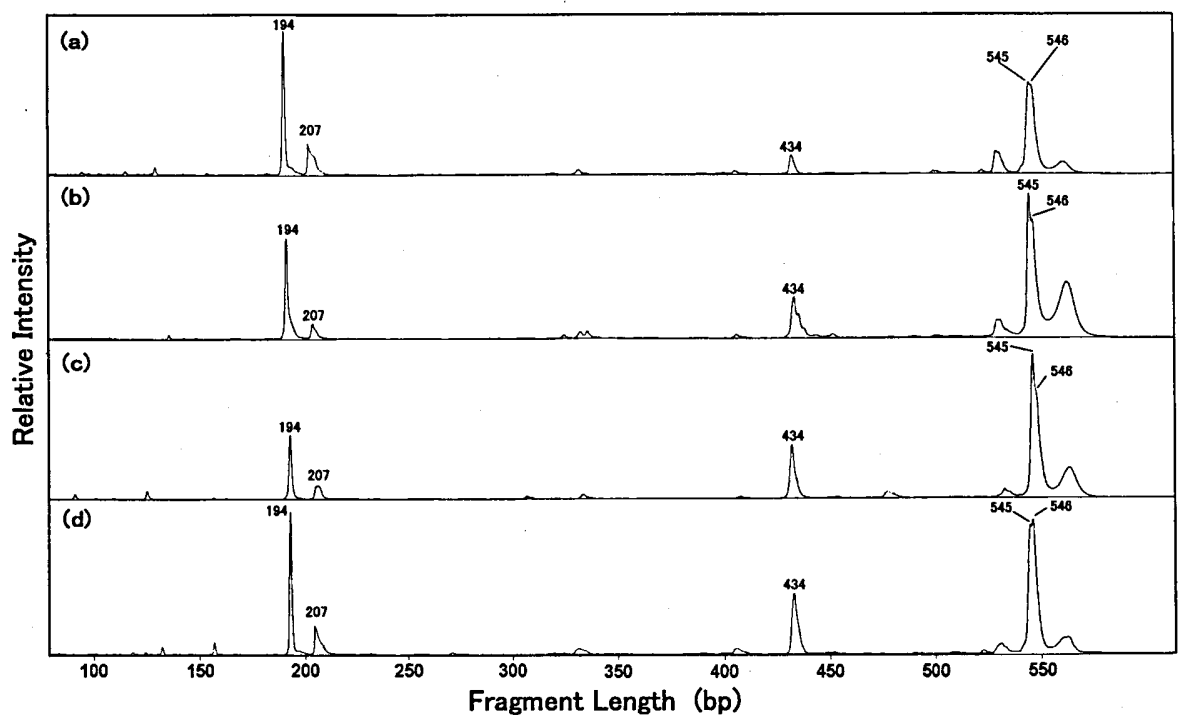

Fig. 1. T-RFLP patterns of colony community plated by the pour method and grown on 0.1 TSA medium. (a), (b), (c), and (d) represent T-RFLP patterns of colony communities derived from four soil samples A, B, C, and D. The values shown in Figure are fragment lengths of major T-RF peaks. 


\section{Changes in bacterial community structure due to plating method}

As an example of applying the colony community structure analysis using T-RFLP, the influence of the plating method (pour-plate vs. spread-plate method) in the dilution plate method on the colony community structure was investigated. Suspensions of diluted soils A and B prepared in the above experiment were plated by the spread method. The results of T-RFLP analysis are shown in Fig. 2. On comparison of the results of analyses using the pour-plate method shown in Fig. 1 (a),(b) and spread-plate method shown in Fig. 2 (a),(b), the positions of T-RF were not different and the T-RF patterns were similar. However, the fluorescence intensity of $207-b p$ peak was the highest in the analysis using the spread method, but low in the analysis using the pour method, showing that although the constituent bacterial species were the same in the analyses using the spread and pour methods, the constitution ratios of some bacterial species were different.

Next, using 0.1 TSA + CV medium, the soil sample was plated by the spread and pour methods and compared by the analysis of colony community structure using T-RFLP. The suspension of diluted soil A prepared in the above experiment was plated by the pour and spread methods. The T-RFLP patterns of the colonies grown on 0.1 TSA + CV medium plated by the pour and spread methods are shown in Fig. 3. On comparison of T-RFLP patterns of colonies grown on 0.1 TSA medium (Figs. 1 and 2) and those on 0.1 TSA + CV medium (Fig. 3), the T-RFLP patterns were completely different and no T-RF was consistent, showing that the selectivity of crystal violet allowed different bacterial species to dominate on $0.1 \mathrm{TSA}+\mathrm{CV}$ medium.

Regarding the influence of the plating method on culture on 0.1 TSA + CV medium, the positions of $\mathrm{T}-\mathrm{RF}$ were similar, but changes in the T-RF peak fluorescence intensity were greater than those on 0.1 TSA medium, showing that difference in the plating method does not greatly affect the types of CV-resistant bacteria grown on the medium, but the constitution ratios of some bacterial species were affected.

As described above, the simple and rapid method for analysis of colony community structure using T-RFLP proposed in this study allowed identification of the bacterial community structure with high reproducibility. Furthermore, this method sufficiently

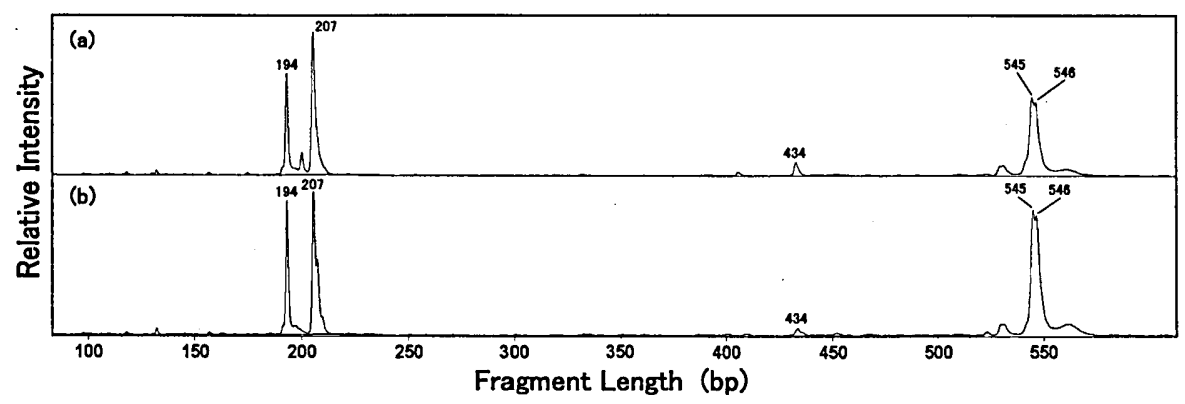

Fig. 2. T-RFLP patterns of colony community plated by the spread method and grown on 0.1 TSA medium. (a) and (b) represent T-RFLP patterns of colony communities derived from two soil samples A and B. The values shown in Figure are fragment lengths of major T-RF peaks. 


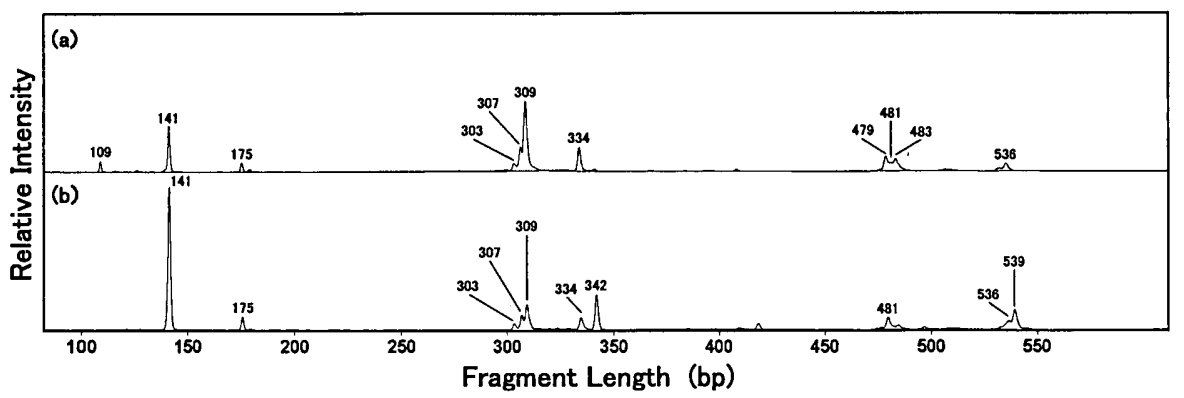

Fig. 3. T-RFLP patterns of colony community grown on 0.1 TSA + CV medium. T-RFLP patterns of soil sample A-derived colony communities plated by (a) pour method and (b) spread method. The values shown in Figure are fragment lengths of major T-RF peaks.

detected differences in the bacterial community structure caused by the different plating methods.

\section{REFERENCES}

Arao, T., S. Okano and T. Kanamori 1998 Phosphplipids, microbial biomass and community structure in soils. Soil Microorganisms, 51: 49-58

Fujie, K., H. Y. Hu, H. Tanaka, K. Urano, K. Saitou and A. Katayama 1998 Analysis of respiratory quinines in soil for characterization of microbiota. Soil Sci. Plant Nutr., 44: 393-404

Katoh, K. 1992 Enumeration, isolation and identification of soil bacteria. In "Experimental Methods of Soil Microorganism", ed. by Soil Microbiological Society of Japan, Yokendo, Tokyo, pp.15-22

Konopka, A., L. Oliver and R. F. Turco 1998 The use of carbon substrate utilization patterns in environmental and ecological microbiology. Microb. Ecol., 35: 103-115

Lane, D. J. 1991 16S/23S rRNA Sequencing. In "Nucleic Acid Techniques in Bacterial systematics", ed. by E. Stackebrandt and M. Goodfellow, Jhon Wiley \& Sons Inc., New York, pp.115-175

Liu, W. T., T. L. Marsh, H. Cheng and L. J. Forney 1997 Characterization of microbial diversity by determining terminal restriction fragment length polymorphisms of genes encoding $16 \mathrm{~S}$ rRNA. Appl. Environ. Microbiol., 63: 4516-4522

Marchesi, J. R., T. Sato, A. J. Weightman, T. A. Martin, J. C. Fry, S. J. Hiom and W. G. Wade 1998 Design and evaluation of useful bacterium-specific PCR primers that amplify genes coding for bacterial $16 \mathrm{~S}$ rRNA. Appl. Environ. Microbiol., 64: 795-799

Marsh, T. L. 1999 Terminal restriction fragment length polymorphism (T-RFLP): An emerging method for characterizing diversity among homologous populations of amplification products. Current Opinion in Microbiology, 2: 323-327

Moeseneder, M. M., J. M. Arrieta, G. Muyzer, C. Winter and G. J. Herndl 1999 Optimization of Terminal-Restriction Fragment Length Polymorphism (T-RFLP) analysis for complex marine bacterioplankton communities and comparison with Denaturing Gradient Gel Electrophoresis (DGGE). Appl. Environ. Microbiol., 65: 3518-3525

Ranjard, L., F. Poly and S. Nazaret 2000 Monitoring complex bacterial communities using culture-independent molecular techniques: application to soil environment. Res. Microbiol., 151: $167-177$

Torsvik,V., K. Salte, R. Sorheim and J. Goksoyr 1990a Comparison of phenotypic diversity and DNA heterogeneity in a population of soil bacteria. Appl. Environ. Microbiol., 56: 776-781

Torsvik, V., J. Goksoyr and F. L. Daae 1990b High diversity in DNA of soil bacteria. Appl. Environ. Microbiol., 56: $782-787$

Yokoyama, K. 1996 Evaluation of diversity in soil microbial communit. Soil Microorganisms, 47: 1-7 